\title{
Pemberian Anti-Myostatin pada Induk Serta Keragaman Gen Myostatin dan Asosiasinya terhadap Potongan Karkas Anak Ayam Sentul (F1)
}

\author{
Maternal Immunization Against Myostatin, Myostatin Gene Polymorphism and Association to Carcass Trait \\ in Sentul Chicken (F1)
}

\author{
R. Fastawa1, C. Sumantri², A. Gunawan ${ }^{2}$, \& S. Murtini ${ }^{3}$ \\ ${ }^{1}$ Mahasiswa Pascasarjana Program Studi Ilmu Produksi dan Teknologi Peternakan, Fakultas Peternakan, IPB \\ ${ }^{2}$ Departemen Ilmu Produksi dan Teknologi Peternakan, Fakultas Peternakan, IPB \\ ${ }^{3}$ Departemen Ilmu Penyakit Hewan dan Kesmavet, Fakultas Kedokteran Hewan, IPB \\ Fakultas Peternakan Institut Pertanian Bogor \\ Jln. Agatis, Kampus IPB Dramaga, Bogor, 16680, Indonesia \\ Email koresponden author: rajmafastawa@gmail.com
}

\begin{abstract}
Myostatin (MSTN), a member of the transforming growth factor $\beta$ (TGF- $\beta$ ) superfamily, is a negative regulator of skeletal muscle growth. Improving muscle growth is very important to increase the economic value of Indonesian indigenous chicken especially in sentul chicken. This study was aimed to identify the polymorphism of the Myostatin gene in sentul indonesian indigenous chicken with maternal immunization against Myostatin on post hatch and to evaluate its effect on carcass traits. In this study, 48 Sentul hens for up to 6 months have been divided into three groups with 16 birds in each group: CON, KLH, and KLH-MSTN. The CON group has not received immunization, the KLH group has been immunized with $1 \mathrm{mg}$ of KLH, and KLH-MSTN has been immunized with $1 \mathrm{mg}$ of KLH-MSTN conjugate intramuscularly. The effects of each group have been observed on $F 1$ carcass production. The gene polymorphism was identified using PCR-RFLP and the effect of genotype on carcass chacteristics were analyzed using SAS General Linear Model Procedure. The product of amplification was $247 \mathrm{bp}$. This locus was polymorphic in sentul chicken with two alleles ( $G$ and $T$ ) and three genotypes (GG, GT, TT). Association analysis were not significant in carcass characteristics. The result of this study showed that interaction of each group with genotype not significant on carcass weight of $F 1$ chicken sentul each age group. F1 sentul chicken 12 week-old significant association of genotype was observed only in thighs weight while 20 week-old was significant in live weight, carcass weight, breast weight, wings weight, thighs weight, drum sticks weight, breast muscle weight, thighs muscle weight and drum sticks muscle weight. These results suggest that no effect genotype on maternal immunization against myostatin to stimulate carcass characteristic in sentul chickens.
\end{abstract}

Keywords: Myostatin, sentul chicken, maternal immunization, carcass

\section{PENDAHULUAN}

Ayam sentul merupakan salah satu sumber daya genetik asli dari daerah Ciamis Jawa Barat. Keunggulan ayam ini berupa pertumbuhannya relatif cepat dan produksi telur yang tinggi. Potensi tersebut menjadikan Ayam sentul dapat digunakan sebagai komoditas industri kerakyatan ayam lokal. Pemerintah saat ini sudah memberikan perhatian serius untuk mengembangkan ayam sentul. Pengembangan Ayam sentul penting dilakukan selain untuk menjaga ayam sentul dari kepunahan, juga untuk menggali potensi genetik yang ada dalam ternak tersebut, demi memaksimalkan pemanfaatannya (Hidayat dan Sopiyana 2010). Produktivitas ayam sentul dalam menghasikan daging lebih unggul dibandingkan dengan ayam kampung, sehingga memiliki potensi sebagai ternak penghasil daging. Hasil yang diharapkan pada pemeliharaan ayam penghasil daging adalah diperolehnya bobot badan pada akhir pemeliharaan yang tinggi dan selanjutnya dapat diperoleh bobot karkas yang tinggi pula. Keberhasilan pemeliharaan ayam penghasil daging adalah diperolehnya persentase karkas yang tinggi (Priyatno 2000). Salah satu cara meningkatkan produktifitas dengan peningkatan mutu genetik ternak ayam melalui seleksi. Kemajuan bioteknologi di bidang genetika molekuler dapat dijadikan alternatif yang efektif, akurat dan efesien melalui penciri genetik berdasarkan gen-gen fungsional pengontrol pertumbuhan dan produksi daging. Salah satu gen yang merupakan gen utama dan penentu dalam mengontrol sifat pertumbuhan dan produksi daging adalah gen Myostatin (MSTN).

Gen MSTN atau growth differentiations factor 8 (GDF8) merupakan anggota dari superfamily transforming 
growth factor- $\beta$ (TGF- $\beta$ ) yang berfungsi sebagai regulator negatif dari pertumbuhan otot skeletal (Ye et al. 2007; Najl et al. 2014). Beberapa penelitian telah menunjukkan bahwa ada korelasi negatif antara gen MSTN dan massa otot dengan berbagai kondisi fisiologis atau patologis yang menyebabkan penurunan atau peningkatan otot pada hewan (Armand et al. 2003; Kirk et al. 2000; Lalani et al. 2000; Mendler et al. 2000; Wehling et al. 2000). Penurunan aktivitas MSTN menyebabkan peningkatan pembentukan massa otot (Whittemore et al. 2003). Beberapa metode telah dilakukan dalam menekan ekspresi myostatin pada ayam, antara lain injeksi antigen secara in-ovo saat masa pertumbuhan embrionik (Bhattacharya et al. 2017), injeksi antigen myostatin pada induk juga berhasil menurunkan ekspresi gen myostatin pada turunannya (Mendler et al. 2000).

Injeksi antigen MSTN pada induk dapat memunculkan antibodi myostatin yang dapat menekan aktivitas biologis MSTN pada generasi berikutnya. Keyhole limpet hemocyanin (KLH) digunakan secara ekstensif sebagai protein pengikat dalam produksi antibodi untuk penelitian. Antigen myostatin tidak bersifat imunogenik sehingga memerlukan bantuan KLH untuk merangsang respon dari sistem kekebalan tubuh dalam bentuk produksi antibodi (Moon et al. 2005). Pada ayam, pemberian antigen MSTN meningkatkan berat badan serta otot yang dibuktikan dengan peningkatan massa tubuh, area penampang melintang seluruh otot dan area serat otot (Bhattacharya et al. 2017). Selain itu, pemberian antibodi MSTN secara in-ovo meningkatkan pertumbuhan otot kerangka, namun metode ini dapat menurunkan daya tetas dan membutuhkan waktu yang lama dalam pemberian antigen tersebut. Penyuntikan antigen myostatin pada induk dapat menjadi metode yang efektif dalam upaya menurunkan aktivitas biologis myostatin dengan tujuan meningkatkan pertumbuhan massa otot ayam. Peningkatan pertumbuhan otot ayam sentul sangat penting untuk meningkatkan nilai ekonominya.

Penelitian ini dilakukan untuk mengidentifikasi keragaman gen MSTN serta asosiasinya terhadap potongan karkas pada anak ayam sentul (F1) dengan pemberian antigen MSTN pada induk.

\section{MATERI DAN METODE}

\section{Lokasi dan Waktu}

Penelitian ini telah dilaksanakan pada bulan Maret 2017 sampai bulan Januari 2018. Penelitian dilaksanakan di Laboraturium Lapang Ternak Terpadu Fakultas Peternakan IPB dan di Laboraturium Genetika Molekuler Ternak, Fakultas Peternakan Institut Pertanian Bogor.

\section{Materi}

Ayam sentul berumur 6 bulan sebanyak 60 ekor (48 ekor betina dan 12 ekor jantan) ekor dibagi menjadi tiga kelompok dengan 20 ekor (16 ekor betina dan 4 ekor jantan) di masing-masing kelompok. Ketiga kelompok tersebut diberi label masing-masing yaitu kontrol, KLH, dan KLHMSTN.

Total sampel yang digunakan untuk sifat fenotipik yaitu 174 ekor ayam sentul, terdiri dari 145 ekor berumur 12 minggu dan 29 ekor berumur 20 minggu. Total sampel yang digunakan pada tahap identifikasi gen myostatin adalah 100 sampel DNA ayam sentul, terdiri atas masing-masing 72 ekor anak ayam sentul umur 12 minggu dan 28 ekor umur 20 minggu.

\section{Preparasi Antigen Myostatin}

\section{Prosedur}

Antigen myostatin yang digunakan merupakan koleksi antigen yang berasal dari universitas Hawaii At Manoa. Fragmen peptida (VFLQKYPHTHLVHQA) yang mewakili urutan asam amino dari 50-64 dari bentuk aktif myostatin (MSTN) dipilih sebagai antigen. Peptida akan disintesis dan dikonjugasikan ke keyhole limpet hemocyanin (KLH). KLH sebagai hapten atau molekul yang merangsang tubuh memproduksi molekul antibodi dengan cara konjugasi dengan molekul yang lebih besar atau disebut molekul pembawa (carrier).

\section{Pemeliharaan Ayam dan Injeksi Antigen Myostatin}

Kelompok kontrol tidak diberi perlakuan, kelompok KLH dilakukan injeksi konjungat KLH $1 \mathrm{mg}$ /ekor dan kelompok MSTN diinjeksi dengan konjugat antigen KLHMSTN $1 \mathrm{mg}$ /ekor secara intramuskular. Injeksi konjungat antigen KLH-MSTN akan dilakukan sebanyak tiga kali pemberian dengan selang waktu setiap pemberian yaitu 3 minggu.

Ayam akan dipelihara dengan model kandang kelompok, setiap kelompok perlakuan dipelihara secara terpisah. Ayam jantan di setiap kelompok akan ditukar setiap minggu. Pemberian pakan sebanyak 100 gr/ekor/hari yang diberikan 2 kali sehari (pagi dan sore), pemberian air diberikan secara adlibitum.

Pengumpulan telur mulai dilakukan 3 minggu setelah pemberian perlakuan terakhir. Telur dikumpulkan setiap hari dan disimpan pada suhu ruang tidak lebih dari 4 hari sampai inkubasi. Antibodi anti-myostatin akan dianalisis dari kuning telur. Sisa telur akan ditetas dan anak ayam dipelihara sampai 12 minggu sampai 20 minggu. Selama pemeliharaan ayam akan divaksinasi dengan vaksin ND pada hari ke-4 dan minggu ke-4.

\section{Pemeliharaan Anak Ayam}

Ayam dipelihara di Laboraturium Lapang Ternak Terpadu Fakultas Peternakan IPB. Sebelum pemeliharaan, kandang disanitasi dengan desinfektan. DOC diberi nomor identitas pada bagian sayap. Ayam dipelihara pada kandang koloni. Pakan yang diberikan adalah pakan komersial untuk ayam ras pedaging fase stater (BR511 diproduksi oleh PT. Charoen Pokphand) dan dedak padi yang diperoleh dari penggilingan padi di wilayah Situ Gede, Dramaga. Pemberian 100\% pakan komersial pada minggu ke-1 sampai minggu ke-3, dilanjutkan dengan perbandingan $60 \%$ pakan komersial : $40 \%$ dedak padi sampai minggu ke-20. Pada umur 4 hari, 3 minggu, dan 8 minggu dilakukan vaksinasi ND untuk seluruh ayam dan pada umur 12 minggu dan 20 minggu ayam dipotong kemudian ditimbang.

\section{Bobot Potong}

Ayam akan disembelih pada umur 12 dan 20 minggu untuk mengumpulkan data komponen karkas. Ayam yang telah dipotong menjadi karkas, kemudian 
dipotong menjadi potongan komersial. Pengukuran komponen karkas termasuk bobot hidup, berat karkas, berat potongan komersial (dada, paha, punggung, dan sayap), otot (otot dada dan otot paha), dan persentase karkas.

\section{Ekstraksi DNA}

Ekstraksi DNA dimulai dengan pengambilan sampel darah. Sebanyak $1 \mathrm{~mL}$ sampel darah diambil dengan menggunakan spoit pada vena brachiais di bagian sayap, kemudian darah dimasukkan ke dalam tabung 1,5 mL yang telah diisi dengan serbuk Ethylenediaminetetraacetic (EDTA). Ekstraksi DNA dilakukan dengan menggunakan metode Sambrook et al. (1989).

\section{Amplifikasi Polymerase Chain Reaction (PCR)}

Amplifikasi fragmen gen MSTN dilakukan menggunakan metode polymerase chain reaction (PCR). Primer yang digunakan dapat dilihat pada Tabel 1. Sebanyak $0.5 \mu \mathrm{L}$ DNA hasil ekstraksi diambil dan dimasukkan kedalam tabung genotype dan ditambahkan $14 \mu \mathrm{L}$ larutan premix. Premix terdiri atas $0,3 \mu \mathrm{L}, 6,2 \mu \mathrm{L}$ DW, dan 7,5 $\mu \mathrm{L}$ master mix. Campuran tersebut diinkubasi menggunkan mesin PCR thermocycler untuk proses amplifikasi. Proses amplifikasi memiliki 3 tahapan. Tahap pertama yaitu proses denaturasi awal pada $95{ }^{\circ} \mathrm{C}$ selama 5 menit yang dilakukan 1 siklus. Tahap kedua dilakukan 30 siklus meliputi proses denaturasi pada suhu $95{ }^{\circ} \mathrm{C}$ selama 10 detik, proses annealing pada suhu $60{ }^{\circ} \mathrm{C}$ selama 20 detik dan proses ekstensi $72{ }^{\circ} \mathrm{C}$ selama 30 detik. Tahap terakhir adalah pemanjangan primer pada suhu $72{ }^{\circ} \mathrm{C}$ selama sepuluh menit. Selanjutnya diinkubasi pada suhu 4 ${ }^{\circ} \mathrm{C}$ hingga digunakan pada analisis selanjutnya.

\section{Restriction Fragment Length Polymorphism (RFLP)}

Penentuan genotype gen MSTN pada exon 2 menggunakan metode RFLP. Produk PCR diambil sebanyak $4 \mu \mathrm{L}$ dan dipindahkan ke tabung 0,5 $\mathrm{mL}$. Campuran pereaksi enzim restriksi yang terdiri atas 0,9 $\mu \mathrm{L}$ DW, 0,4 $\mu \mathrm{L}$ enzim restriksi, dan $0,7 \mu \mathrm{L}$ buffer enzim dihomogenkan dan diambil masing-masing sebanyak 2 $\mu \mathrm{L}$ untuk setiap sampel. Enzim pemotong yang digunakan untuk gen MSTN ekson 2 adalah $B s r l$. Campuran sampel tersebut diinkubasi pada suhu yang direkomendasikan selama 8 jam dan selanjutnya dielektroforesis dengan agarosa gel 2,5\%.

\section{Visualisasi Fragmen DNA}

Produk PCR-RFLP dielektroforesis menggunakan agarose gel dengan konsentrasi 2,5\%. Sebanyak 0,6 g serbuk agarose ditambahkan dengan $30 \mathrm{~mL} 0,5 \times$ TBE . Campuran tersebut dipanaskan hingga mendidih dan ditambahkan dengan 1,8 $\mu \mathrm{L}$ fluorosafe, kemudian dicetak pada cetakan hingga mengeras. Masing-masing sampel DNA hasil PCR sebanyak $5 \mu \mathrm{L}$ ditambahkan dengan 1 $\mu \mathrm{L}$ loading dye dan dimasukkan ke dalam sumur-sumur di dalam gel, kemudian dielektroforesis pada larutan 0,5 $\times$ TBE dengan voltase 100 volt selama kurang lebih 30 sampai 45 menit. Pita-pita DNA akan tampak dengan bantuan sinar ultra violet pada mesin UV Transilluminator.

\section{Analisis Data}

Genotipe yang diperoleh dari PCR-RFLP, kemudian dihitung nilai frekuensi alel, frekuensi genotype, nilai keseimbangan Hardy-Weinberg, heterozigositas pengamatan, dan heterozigositas harapan berdasarkan rumus berikut:

1. Frekuensi alel (Nei 1987) :

$$
\mathrm{Xi}=\frac{\left(2 n i i+\sum_{j \neq 1} n i j\right)\left(2 n i i+\sum_{j \neq 1} n i j\right)}{(2 N)}
$$

Keterangan :

$\mathrm{Xi}=$ frekuensi alel ke-i;

Nii = jumlah individu bergenotipe ii;

$\mathrm{Nij}=$ jumlah individu bergenotipe ij; dan

$\mathrm{N}=$ total sampel.

2. Frekuensi genotipe (Nei 1987) :

$$
\mathrm{Xii}=\frac{\sum_{i=1}^{n} n i \sum_{i=1}^{n} n i}{(N) \quad(N)}
$$

Keterangan :

Xii = frekuensi genotype ke-i;

$\mathrm{Ni}=$ jumlah individu bergenotipe ii; dan

$\mathrm{N}=$ total sampel

3. Keseimbangan Hardy-Weinberg (H-W) (Hartl dan Clark 1997) :

$$
\mathrm{X}^{2}=\sum \frac{(\mathrm{O}-\mathrm{E})^{2}(\mathrm{O}-\mathrm{E})^{2}}{\mathrm{E}}
$$

Keterangan :

$\mathrm{X}^{2}=$ nilai chi-square;

$\mathrm{O}=$ jumlah genotype teramati; dan

$\mathrm{E}=$ jumlah genotype harapan

4. Heterozigositas (Nei 1987) :

$$
\begin{aligned}
& \text { Ho }=\sum_{i \neq j} \frac{N_{1 j k}}{N} \sum_{i \neq j} \frac{N_{1 j k}}{N} \\
& \text { He }=1-\sum_{i=1}^{n} P_{1 i}{ }^{2} \sum_{i=1}^{n} P_{1 i}{ }^{2}
\end{aligned}
$$

Keterangan :

Ho = heterozigositas pengamatan;

Nijk = jumlah individu heterozigot pada lokus ke-1;

$\mathrm{N}$ = jumlah individu yang diamati;

$\mathrm{He}=$ Heterozigositas harapan; dan

$\mathrm{P}_{1 \mathrm{i}}=$ frekuensi alel ke-1.

\section{Asosiasi Gen Myostatin terhadap Bobot Potong}

Asosiasi antara genotype gen myostatin terhadap potongan karkas komersial, pada ayam sentul dianalisis dengan analysis of varian (ANOVA), menggunakan rancangan acak

Tabel 1 Primer gen myostatin (MSTN) ekson 2

\begin{tabular}{llll}
\hline Posisi & Enzim & Sekuen Primer & Pustaka \\
\hline Exon 2 & Bsrl & F :5'TGCATCCACTCTGTTACCAA & Zhang et al. (2011) \\
& & R :5'CTGCCATTCTCGAAGCAATA & \\
\hline
\end{tabular}


kelompok (RAK), faktor jenis kelamin sebagai kelompok, dengan model (Mattjik dan Sumertajaya 2002) sebagai berikut :

$\mathrm{Yij}=\mu+\alpha_{\mathrm{k}}+\mathrm{P}_{\mathrm{i}}+\mathrm{Q}_{\mathrm{j}}+\left(\mathrm{PQ}_{\mathrm{ij}}\right)+\varepsilon_{\mathrm{ijk}}$

Keterangan :

Yij = nilai pengamatan;

$\mu=$ nilai tengah umum;

$\alpha_{\mathrm{k}}=$ pengaruh faktor kelompok pada taraf ke-k;

$\mathrm{P}_{\mathrm{i}}=$ pengaruh perlakuan Kontrol, KLH dan KLH-MSTN taraf ke-i;

$\mathrm{Q}_{\mathrm{j}}=$ pengaruh genotipe pada taraf ke-i;

$\varepsilon_{\mathrm{kij}}=$ pengaruh galat percobaan dari perlakuan ke i pada ulangan ke $\mathrm{j}$.

\section{HASIL DAN PEMBAHASAN}

\section{Karakteristik Gen MSTN}

Amplifikasi Gen MSTN pada ayam sentul

Gen MSTN pada ekson 2 diamplifikasi dengan panjang $247 \mathrm{pb}$. Hal ini sesuai dengan panjang produk PCR yang di amplifikasi oleh Khaerunnisa et al. (2016). Hasil amplifikasi gen MSTN pada exon 2 di sajikan pada Gambar 1.
Hasil RFLP menggunakan enzim BsrI pada fragmen gen MSTN berhasil mengidentifikasi 2 alel yaitu alel $\mathrm{G}$ dan T. Kedua Alel tersebut menghasilkan 3 genotipe yaitu GG, GT, dan TT. Alel G memiliki 3 pita yaitu 144 pb, 64 pb, dan 39 pb. Alel T memiliki 4 pita yaitu 99 pb, 64 pb, 45 pb dan 39 pb. Kombinasi Alel G dan T memiliki 5 pita yaitu 144 pb, 99 pb, 64 pb, 45 pb dan 39 pb. Hasil visualisasi PCRRFLP gen MSTN|BsrI dapat dilihat pada Gambar 2. SNP ini dilaporkan terjadi pertukaran timin menjadi nukleotida guanin dan perubahan asam amino leusin menjadi arginin (Ye et al. 2007).

\section{Keragaman Heterosigositas dan keseimbangan Hardiweinberg Gen MSTN}

Frekuensi genotipe, alel, heterosigositas dan chisquare gen MSTN ayam sentul di sajikan pada Tabel 2. Frekuensi genotipe tertinggi di setiap perlakuan yaitu genotipe TT dan terendah adalah genotipe GG. Hal ini menunjukkan bahwa frekuensi genotipe TT memiliki peluang kemunculan lebih tinggi. Penelitian yang dilakuan oleh Khaerunnisa et al. (2016), menunjukkan bahwa frekuensi genotipe GG paling rendah pada ayam lokal indonesia.

Frekuensi alel $\mathrm{T}$ lebih tinggi di bandingkan denga

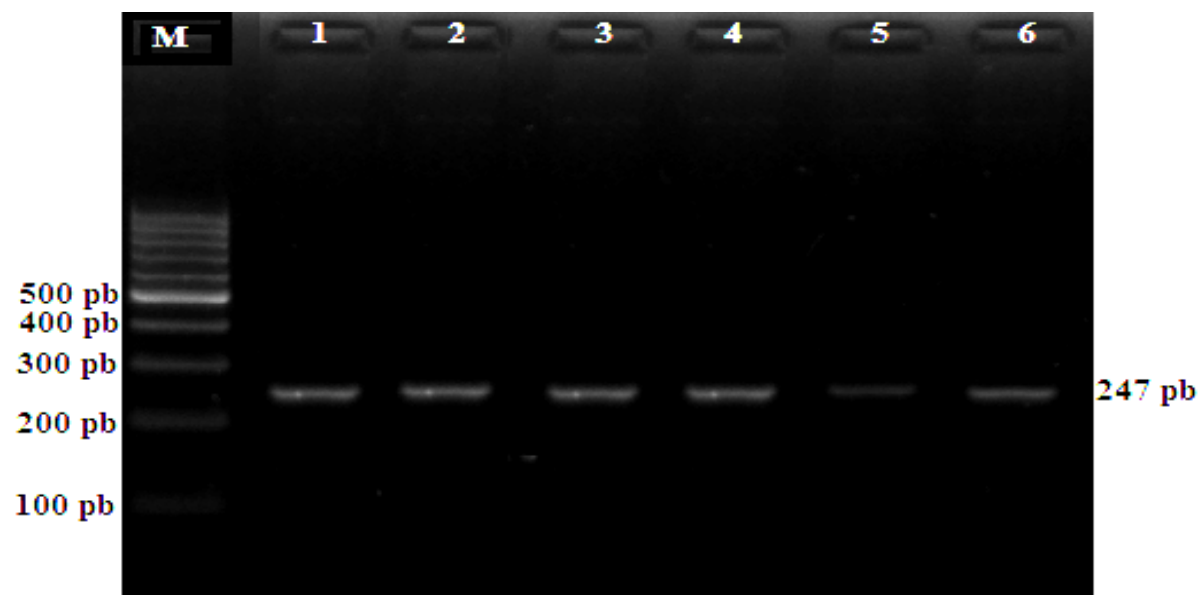

Gambar 1. Hasil amplifikasi gen MSTN pada gel agarose 1.5\%. M: marker; 1-6: sampel

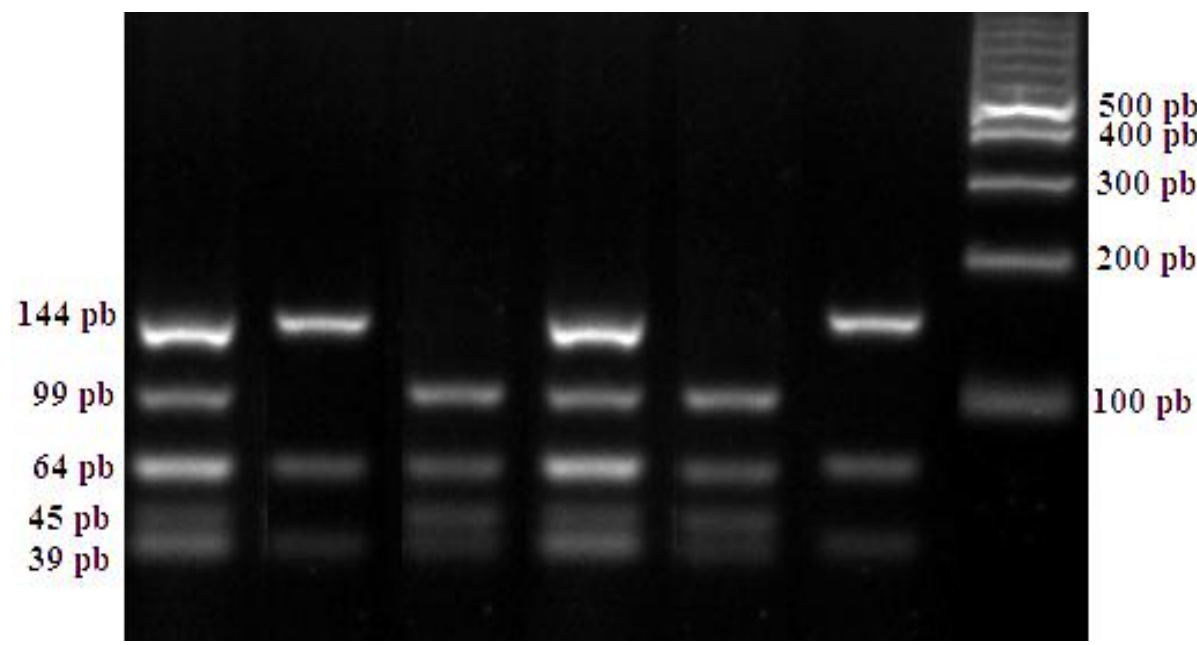

Gambar 2. Visualisasi hasil PCR-RFLP gen MSTN|BsrI pada gel agarose 2.5\% 
Fastawa et al.

Jurnal Ilmu Produksi dan Teknologi Hasil Peternakan 7 (1): 22-28

Tabel 2 Frekuensi genotipe, alel, Heterosigositas dan chi-square gen MSTN ekson 2

\begin{tabular}{|c|c|c|c|c|c|c|c|c|c|}
\hline \multirow[t]{2}{*}{ Sampel } & \multirow[t]{2}{*}{$\mathrm{N}$} & \multicolumn{3}{|c|}{ Genotipe } & \multicolumn{2}{|c|}{ Alel } & \multirow[t]{2}{*}{$\mathrm{He}$} & \multirow[t]{2}{*}{ Но } & \multirow[t]{2}{*}{$\mathrm{x}^{2}$} \\
\hline & & GG & GT & $\mathrm{TT}$ & G & $\mathrm{T}$ & & & \\
\hline Kontrol & 33 & 0,18 & 0,33 & 0,48 & 0,35 & 0,65 & 0,33 & 0,45 & tn \\
\hline KLH & 28 & 0,07 & 0,46 & 0,46 & 0,3 & 0,7 & 0,46 & 0,42 & tn \\
\hline MSTN & 40 & 0,08 & 0,43 & 0,5 & 0,29 & 0,71 & 0,43 & 0,41 & tn \\
\hline Total & 101 & 0,11 & 0,4 & 0,5 & 0,31 & 0,69 & 0,4 & 0,43 & tn \\
\hline
\end{tabular}

$\mathrm{n}=$ jumlah individu; $\mathrm{tn}=$ tidak nyata; $\mathrm{He}=$ heterozigositas harapan; $\mathrm{Ho}=$ heterosigositas pengamatan; $\mathrm{x}^{2}=$ chi-square

Tabel 3. Asosiasi gen MSTN dengan bobot potong, bobot karkas dan persentase karkas ayam sentul umur 12 minggu

\begin{tabular}{|c|c|c|c|c|c|c|c|c|c|c|}
\hline \multirow[t]{2}{*}{ Parameter } & \multicolumn{3}{|c|}{ Kontrol } & \multicolumn{3}{|c|}{ KLH } & \multicolumn{3}{|c|}{ MSTN } & \multirow[t]{2}{*}{$\mathrm{P}^{*} \mathrm{G}$} \\
\hline & GG (4) & GT (7) & TT (11) & GG (2) & GT (8) & TT (8) & GG (2) & GT (13) & TT (17) & \\
\hline Bobot hidup (g) & $859,0 \pm 59,2$ & $776,3 \pm 26,2$ & $802,1 \pm 23,6$ & $894,0 \pm 106,0$ & $863,6 \pm 39,9$ & $909,1 \pm 50,9$ & $889,5 \pm 92,5$ & $873,8 \pm 31,2$ & $915,2 \pm 38,1$ & tn \\
\hline Bobot potong (g) & $832,8 \pm 61,8$ & $754,0 \pm 23,2$ & $780,1 \pm 22,5$ & $864,0 \pm 101,0$ & $829,1 \pm 42,2$ & $868,9 \pm 60,0$ & $838,0 \pm 103,0$ & $833,6 \pm 29,9$ & $872,8 \pm 36,6$ & tn \\
\hline Bobot karkas (g) & $509,5 \pm 42,3$ & $464,1 \pm 16,2$ & $489,1 \pm 16,2$ & $545,5 \pm 66,5$ & $525,9 \pm 28,8$ & $544,6 \pm 25,6$ & $540,5 \pm 71,5$ & $507,1 \pm 17,6$ & $550,9 \pm 24,4$ & tn \\
\hline Bobot dada (g) & $127,0 \pm 12,0$ & $123,0 \pm 4,3$ & $129,7 \pm 4,1$ & $149,0 \pm 12,0$ & $135,7 \pm 6,2$ & $137,5 \pm 8,6$ & $140,0 \pm 20,0$ & $133,1 \pm 4,5$ & $138,9 \pm 5,6$ & tn \\
\hline Bobot punggung (g) & $117,0 \pm 8,6$ & $103,0 \pm 5,1$ & $113,5 \pm 5,5$ & $140,0 \pm 25,0$ & $124,8 \pm 10,1$ & $130,5 \pm 10,2$ & $124,0 \pm 17,0$ & $116,5 \pm 5,8$ & $128,2 \pm 7,5$ & tn \\
\hline Bobot sayap (g) & $80,5 \pm 6,9$ & $70,7 \pm 2,5$ & $72,8 \pm 3,6$ & $80,5 \pm 10,5$ & $80,3 \pm 3,61$ & $82,2 \pm 2,8$ & $80,5 \pm 8,5$ & $78,5 \pm 2,9$ & $81,9 \pm 2,9$ & tn \\
\hline Bobot thighs (g) & $89,5 \pm 9,2$ & $82,6 \pm 3,0$ & $84,3 \pm 3,3$ & $78,0 \pm 2,0$ & $85,0 \pm 4,4$ & $96,6 \pm 4,3$ & $102,0 \pm 13,0$ & $89,9 \pm 3,1$ & $96,1 \pm 4,7$ & tn \\
\hline Bobot drumsticks (g) & $89,5 \pm 6,6$ & $79,7 \pm 2,6$ & $82,5 \pm 2,7$ & $96,0 \pm 19,0$ & $88,4 \pm 4,5$ & $93,0 \pm 4,4$ & $92,5 \pm 10,5$ & $87,2 \pm 3,1$ & $96,7 \pm 4,9$ & tn \\
\hline $\begin{array}{l}\text { Bobot Pectoralis } \\
\text { mayor }(\mathrm{g})\end{array}$ & $64,7 \pm 7,1$ & $57,5 \pm 1,8$ & $62,8 \pm 1,6$ & $75,5 \pm 1,5$ & $68,0 \pm 3,5$ & $68,7 \pm 4,9$ & $68,0 \pm 10,0$ & $65,9 \pm 2,4$ & $68,8 \pm 2,8$ & tn \\
\hline $\begin{array}{l}\text { Bobot Pectoralis } \\
\text { minor }(\mathrm{g})\end{array}$ & $24,2 \pm 2,9$ & $24,0 \pm 1,1$ & $26,4 \pm 0,8$ & $28,5 \pm 1,5$ & $25,4 \pm 1,8$ & $26,5 \pm 1,8$ & $28,5 \pm 3,5$ & $26,3 \pm 0,8$ & $27,7 \pm 1,2$ & tn \\
\hline $\begin{array}{l}\text { Bobot daging thighs } \\
\text { (g) }\end{array}$ & $58,7 \pm 6,5$ & $53,5 \pm 1,8$ & $58,7 \pm 2,3$ & $52,0 \pm 1,0 \mathrm{~b}$ & $62,0 \pm 3,4 \mathrm{ab}$ & $68,6 \pm 2,5 \mathrm{a}$ & $83,5 \pm 0,5$ & $69,6 \pm 3,9$ & $69,1 \pm 3,6$ & tn \\
\hline $\begin{array}{l}\text { Bobot daging } \\
\text { drumsticks (g) }\end{array}$ & $54,0 \pm 4,4$ & $48,4 \pm 1,8$ & $52,0 \pm 1,6$ & $55,5 \pm 6,5$ & $55,5 \pm 3,0$ & $58,9 \pm 2,7$ & $57,5 \pm 6,5$ & $55,8 \pm 2,7$ & $57,1 \pm 2,6$ & tn \\
\hline Bobot karkas (\%) & $59,2 \pm 1,6$ & $59,8 \pm 1,0$ & $60,9 \pm 0,7$ & $61,0 \pm 0,2$ & $60,8 \pm 1,3$ & $60,2 \pm 1,0$ & $60,5 \pm 1,7$ & $58,1 \pm 0,5$ & $60,2 \pm 0,9$ & tn \\
\hline Bobot dada (\%) & $24,9 \pm 1,3$ & $26,5 \pm 0,7$ & $26,5 \pm 0,5$ & $27,4 \pm 1,1$ & $25,9 \pm 0,6$ & $25,1 \pm 0,6$ & $25,8 \pm 0,2$ & $26,3 \pm 0,5$ & $25,3 \pm 0,5$ & tn \\
\hline Bobot punggung (\%) & $23,0 \pm 0,6$ & $22,1 \pm 0,4$ & $23,1 \pm 0,4$ & $25,5 \pm 1,4$ & $23,5 \pm 0,8$ & $23,7 \pm 0,8$ & $22,9 \pm 0,1$ & $22,8 \pm 0,4$ & $23,1 \pm 0,4$ & tn \\
\hline Bobot sayap (\%) & $15,8 \pm 0,4$ & $15,2 \pm 0,3$ & $14,8 \pm 0,4$ & $14,7 \pm 0,1$ & $15,3 \pm 0,3$ & $15,2 \pm 0,4$ & $14,9 \pm 0,4$ & $15,5 \pm 0,2$ & $14,9 \pm 0,2$ & tn \\
\hline Bobot thighs (\%) & $17,4 \pm 0,4$ & $17,7 \pm 0,1$ & $17,2 \pm 0,2$ & $14,4 \pm 1,4 \mathrm{~b}$ & $16,3 \pm 0,7 \mathrm{ab}$ & $17,7 \pm 0,4 \mathrm{a}$ & $18,8 \pm 0,1$ & $17,7 \pm 0,2$ & $17,4 \pm 0,2$ & tn \\
\hline $\begin{array}{l}\text { Bobot drumsticks } \\
(\%)\end{array}$ & $17,6 \pm 0,5$ & $17,2 \pm 0,3$ & $16,8 \pm 0,3$ & $17,4 \pm 1,3$ & $16,9 \pm 0,7$ & $17,1 \pm 0,5$ & $17,1 \pm 0,3$ & $17,2 \pm 0,2$ & $17,5 \pm 0,3$ & tn \\
\hline $\begin{array}{l}\text { Bobot Pectoralis } \\
\text { mayor }(\%)\end{array}$ & $12,6 \pm 0,6$ & $12,5 \pm 0,6$ & $12,9 \pm 0,3$ & $14,0 \pm 1,4$ & $13,0 \pm 0,5$ & $12,5 \pm 0,4$ & $12,5 \pm 0,2$ & $13,0 \pm 0,3$ & $12,5 \pm 0,2$ & tn \\
\hline $\begin{array}{l}\text { Bobot Pectoralis } \\
\text { minor }(\%)\end{array}$ & $4,7 \pm 0,2$ & $5,2 \pm 0,3$ & $5,4 \pm 0,1$ & $5,2 \pm 0,3$ & $4,8 \pm 0,2$ & $4,8 \pm 0,2$ & $5,2 \pm 0,1$ & $5,2 \pm 0,1$ & $5,0 \pm 0,1$ & tn \\
\hline $\begin{array}{l}\text { Bobot daging } \\
\text { thighs }(\%)\end{array}$ & $11,4 \pm 0,4$ & $11,5 \pm 0,4$ & $12,0 \pm 0,2$ & $9,7 \pm 1,3 \mathrm{~b}$ & $11,8 \pm 0,5 \mathrm{ab}$ & $12,7 \pm 0,6 \mathrm{a}$ & $15,7 \pm 2,2$ & $13,8 \pm 0,8$ & $12,5 \pm 0,3$ & tn \\
\hline $\begin{array}{l}\text { Bobot daging } \\
\text { drumsticks }(\%)\end{array}$ & $10,6 \pm 0,2$ & $10,4 \pm 0,3$ & $10,6 \pm 0,1$ & $10,1 \pm 0,1$ & $10,7 \pm 0,6$ & $10,8 \pm 0,5$ & $10,6 \pm 0,2$ & $10,9 \pm 0,2$ & $10,3 \pm 0,1$ & tn \\
\hline
\end{tabular}

Angka yang disertai huruf berbeda pada baris danperlakuan yang sama menunjukkan berbeda nyata $(\mathrm{P}<0.05) ; \mathrm{P} * \mathrm{G}=$ interaksi perlakuan dan genotipe; tn $=$ tidak nyata

frekuensi alel G, pada semua kelompok perlakuan. Seluruh populasi perlakuan yang di analisis menunjukkan bahwa gen MSTN bersifat polimorfik karena memiliki nilai frekuensi alel yang rendah. Menurut Allendorf et al. (2013) suatu populasi diklarifikasi bersifat polimorfik apabila memiliki frekuensi alel korang dari 0,99. Frekuensi gen dalam suatu populasi dapat mengalami perubahan jika terjadi seleksi, Mutasi, pencampuran populasi, inbreeding dan outbreeding serta genetic drift.

Populasi ayam yang diamati memiliki keragaman gen MSTN ekson 2 yang rendah. Nilai Heterozigositas harapan dan pengamatan pada semua populasi menunjukkan nilai yang rendah. Menurut Allendorf et al. (2013) keragaman genetik suatu populasi dinyatakan tinggi apabila nilai heterozigositasnya lebih besar dari 0,5 . heterozigositas digunakan untuk mengetahui keragaman gen dalam suatu populasi yang dapat membantu pada program seleksi untuk generasi berikutnya (Kubota et al. 2007).

Kelompok ayam sentul yang diamati mununjukkkan bahwa populasi berada dalam keseimbangan Hardyweinberg. Hal ini berdasarkan pendapat Allendorf et al. (2013) populasi dikatakan berada dalam keseimbangan jika nilai hitung $x^{2}$ lebih kecil dibandingkan dengan $x^{2}$ 
Fastawa et al.

Jurnal Ilmu Produksi dan Teknologi Hasil Peternakan 7 (1): 22-28

Tabel 4 Asosiasi gen MSTN dengan bobot potong, bobot karkas dan persentase karkas ayam sentul umur 20 minggu

\begin{tabular}{|c|c|c|c|c|c|c|c|c|c|c|}
\hline \multirow[t]{3}{*}{ Parameter } & \multirow{2}{*}{\multicolumn{3}{|c|}{ Kontrol }} & \multirow{2}{*}{\multicolumn{3}{|c|}{ KLH }} & \multirow{2}{*}{\multicolumn{3}{|c|}{ MSTN }} & \multirow[t]{3}{*}{$\mathrm{P} * \mathrm{G}$} \\
\hline & & & & & & & & & & \\
\hline & GG (2) & GT (4) & TT (5) & GG $(0)$ & GT (4) & TT (6) & GG $(0)$ & GT (4) & TT (3) & \\
\hline Bobot hidup (g) & $1806,5 \pm 67,5 \mathrm{a}$ & $975,8 \pm 61,2 b$ & $1212,0 \pm 143,0 \mathrm{~b}$ & - & $1475,8 \pm 8,1$ & $1488,5 \pm 86,7$ & - & $1370,0 \pm 138,0$ & $1474,0 \pm 142,0$ & tn \\
\hline Bobot potong (g) & $1751,5 \pm 65,5 \mathrm{a}$ & $947,3 \pm 60,2 b$ & $1182,0 \pm 138,0 \mathrm{~b}$ & - & $1408,0 \pm 84,6$ & $1417,8 \pm 82,0$ & - & $1329,0 \pm 131,0$ & $1414,0 \pm 136,0$ & tn \\
\hline Bobot karkas (g) & $1182,5 \pm 44,5 \mathrm{a}$ & $644,5 \pm 41,9 b$ & $791,0 \pm 94,3 b$ & - & $947,0 \pm 53,8$ & $962,8 \pm 59,0$ & - & $936,0 \pm 104,0$ & $1026,0 \pm 112,0$ & tn \\
\hline Bobot dada (g) & $294,0 \pm 11,0 \mathrm{a}$ & $178,8 \pm 21,7 \mathrm{~b}$ & $197,0 \pm 23,5 b$ & - & $256,0 \pm 18,0$ & $251,7 \pm 12,3$ & - & $258,3 \pm 28,8$ & $279,3 \pm 38,6$ & tn \\
\hline $\begin{array}{l}\text { Bobot punggung } \\
\text { (g) }\end{array}$ & $301,0 \pm 11,0 \mathrm{a}$ & $156,5 \pm 6,1 b$ & $201,4 \pm 24,0 b$ & - & $218,0 \pm 11,2$ & $225,8 \pm 15,2$ & - & $219,0 \pm 22,4$ & $239,3 \pm 24,8$ & tn \\
\hline Bobot sayap (g) & $173,5 \pm 6,5 \mathrm{a}$ & $88,2 \pm 2,2 b$ & $116,2 \pm 13,9 b$ & - & $112,5 \pm 5,3$ & $121,0 \pm 9,7$ & - & $129,0 \pm 13,7$ & $141,3 \pm 16,8$ & tn \\
\hline Bobot thighs (g) & $202,5 \pm 7,5 a$ & $112,0 \pm 9,8 \mathrm{~b}$ & $135,2 \pm 16,1 b$ & - & $184,3 \pm 10,9$ & $185,7 \pm 10,8$ & - & $169,5 \pm 20,4$ & $186,3 \pm 18,3$ & tn \\
\hline $\begin{array}{l}\text { Bobot } \\
\text { drumsticks (g) }\end{array}$ & $211,0 \pm 8,0 \mathrm{a}$ & $109,0 \pm 4,4 \mathrm{~b}$ & $141,2 \pm 16,8 b$ & - & $176,2 \pm 9,9$ & $178,7 \pm 10,8$ & - & $160,8 \pm 19,4$ & $179,0 \pm 17,6$ & tn \\
\hline $\begin{array}{l}\text { Bobot Pectoralis } \\
\text { mayor }(\mathrm{g})\end{array}$ & $129,0 \pm 8,0 \mathrm{a}$ & $77,2 \pm 5,7 \mathrm{~b}$ & $84,4 \pm 9,7 \mathrm{~b}$ & - & $113,0 \pm 9,0$ & $116,5 \pm 7,5$ & - & $117,3 \pm 13,5$ & $136,0 \pm 8,96$ & tn \\
\hline $\begin{array}{l}\text { Bobot Pectoralis } \\
\text { minor }(\mathrm{g})\end{array}$ & $51,0 \pm 2,0 \mathrm{a}$ & $30,2 \pm 2,7 \mathrm{~b}$ & $34,0 \pm 3,0 \mathrm{~b}$ & - & $41,2 \pm 3,1$ & $41,0 \pm 2,4$ & - & $46,5 \pm 5,9$ & $57,3 \pm 4,06$ & tn \\
\hline $\begin{array}{l}\text { Bobot daging } \\
\text { thighs (g) }\end{array}$ & $130,0 \pm 2,0 \mathrm{a}$ & $71,0 \pm 6,2 b$ & $91,2 \pm 9,7 \mathrm{~b}$ & - & $115,7 \pm 7,1$ & $117,1 \pm 7,1$ & - & $123,5 \pm 14,2$ & $138,0 \pm 15,6$ & tn \\
\hline $\begin{array}{l}\text { Bobot daging } \\
\text { drumsticks (g) }\end{array}$ & $109,0 \pm 4,0 \mathrm{a}$ & $61,7 \pm 4,8 b$ & $74,6 \pm 10,4 \mathrm{~b}$ & - & $99,7 \pm 5,3$ & $101,0 \pm 6,2$ & - & $98,8 \pm 11,4$ & $115,0 \pm 10,4$ & tn \\
\hline $\begin{array}{l}\text { Bobot karkas } \\
(\%)\end{array}$ & $65,4 \pm 0,0$ & $66,0 \pm 0,4$ & $65,2 \pm 0,2$ & - & $64,2 \pm 0,2$ & $64,6 \pm 0,1$ & - & $68,1 \pm 2,3$ & $69,8 \pm 4,8$ & tn \\
\hline Bobot dada (\%) & $24,8 \pm 0,0$ & $27,4 \pm 1,5$ & $24,9 \pm 0,0$ & - & $26,9 \pm 0,5$ & $26,2 \pm 0,2$ & - & $27,6 \pm 0,6$ & $27,1 \pm 1,2$ & tn \\
\hline $\begin{array}{l}\text { Bobot punggung } \\
(\%)\end{array}$ & $25,4 \pm 0,0$ & $24,4 \pm 0,6$ & $25,4 \pm 0,0$ & - & $23,0 \pm 0,2$ & $23,4 \pm 0,1$ & - & $23,4 \pm 0,7$ & $23,3 \pm 0,3$ & tn \\
\hline Bobot sayap (\%) & $14,6 \pm 0,0$ & $13,8 \pm 0,5$ & $14,6 \pm 0,0$ & - & $11,9 \pm 0,3$ & $12,5 \pm 0,2$ & - & $13,8 \pm 0,1$ & $13,7 \pm 0,2$ & tn \\
\hline Bobot thighs (\%) & $17,1 \pm 0,0$ & $17,3 \pm 0,5$ & $17,1 \pm 0,0$ & - & $19,4 \pm 0,1$ & $19,2 \pm 0,0$ & - & $18,0 \pm 0,4$ & $18,2 \pm 0,6$ & tn \\
\hline $\begin{array}{l}\text { Bobot } \\
\text { drumsticks (\%) }\end{array}$ & $17,8 \pm 0,0$ & $17,0 \pm 0,7$ & $17,8 \pm 0,0$ & - & $18,6 \pm 0,0$ & $18,5 \pm 0,0$ & - & $17,1 \pm 0,2$ & $17,4 \pm 0,5$ & tn \\
\hline $\begin{array}{l}\text { Bobot Pectoralis } \\
\text { mayor }(\%)\end{array}$ & $10,8 \pm 0,2$ & $11,9 \pm 0,1$ & $10,6 \pm 0,2$ & - & $11,8 \pm 0,3$ & $12,1 \pm 0,2$ & - & $12,5 \pm 0,3$ & $13,3 \pm 0,6$ & tn \\
\hline $\begin{array}{l}\text { Bobot Pectoralis } \\
\text { minor }(\%)\end{array}$ & $4,3 \pm 0,0$ & $4,6 \pm 0,2$ & $4,3 \pm 0,1$ & - & $4,3 \pm 0,1$ & $4,2 \pm 0,1$ & - & $4,9 \pm 0,2$ & $5,6 \pm 0,3$ & tn \\
\hline $\begin{array}{l}\text { Bobot daging } \\
\text { thighs }(\%)\end{array}$ & $11,0 \pm 0,2$ & $10,9 \pm 0,3$ & $11,6 \pm 0,2$ & - & $12,2 \pm 0,1$ & $12,1 \pm 0,1$ & - & $13,1 \pm 0,1$ & $13,4 \pm 0,7$ & tn \\
\hline $\begin{array}{l}\text { Bobot daging } \\
\text { drumsticks }(\%)\end{array}$ & $9,2 \pm 0,0$ & $9,5 \pm 0,2$ & $9,3 \pm 0,2$ & - & $10,5 \pm 0,0$ & $10,4 \pm 0,0$ & - & $10,5 \pm 0,1$ & $11,2 \pm 0,8$ & tn \\
\hline
\end{tabular}

Angka yang disertai huruf berbeda pada baris dan perlakuan yang sama menunjukkan berbeda nyata $(\mathrm{P}<0.05)$; $\mathrm{P}$ G $=$ interaksi perlakuan dan genotipe; tn $=$ tidak nyata

tabel. Nilai chi square yang tidak signifikan pada taraf $5 \%$ menunjukkan kesesuaian antara hasil pengamatan dan nilai harapan.

Interaksi Perlakuan Pemberian Antigen MSTN dan Gen MSTN serta Asosiasinya dengan Bobot Potong dan Bobot Karkas Ayam sentul

Pemberian perlakuan antigen MSTN pada ayam sentul umur 12 dan 20 minggu tidak berinteraksi dengan genotipe gen MSTN. Hal ini menunjukkan bahwa pemberian perlakuan tersebut memberikan respon yang sama disetiap genotipe dalam populasi. Asosiasi gen MSTN dengan bobot hidup dan bobot potong ayam sentul pada umur 12 dan 20 minggu, disajikan pada Tabel 3 dan 4.

Ayam sentul memiliki sifat pertumbuhan lambat, sehingga pada umur 12 minggu periode pertumbuhan belum mencapai puncak. Pengaruh gen MSTN pada umur 12 minggu memungkinkan belum terlihat, dan baru terlihat pada umur 20 minggu. Menurut Meyliana et al (2015) ayam sentul umur 20 minggu dapat mencapai berat badan
1781 gram pada jantan dan 1289 gram pada betina.

Berdasarkan hasil analisis statistik menunjukkan bahwa ayam sentul kelompok kontrol pada umur 12 minggu tidak terdapat perbedaan yang signifikan $(\mathrm{P}<0,05)$ disetiap genotipe yang diamati. Namun, kelompok KLH menunjukkan genotipe TT lebih tinggi dibandingkan dengan genotipe GG pada bobot daging thighs, persentase Bobot thighs, dan persentase bobot daging thighs. Hal ini sesuai dengan penelitian yang dilakukan oleh Khaerunnisa et al. (2016) padapersilangan ayam kampung dan Cobb broiler, menunjukan genotipe TT menunjukkan bobot karkas yang lebih tinggi. Menurut Ye et al. (2007) alel T menunjukkan efek positif terhadap pertumbuhan otot.

Kergaman gen MSTN pada ekson 2 tidak berasosiasi dengan bobot hidup, bobot karkas maupun potongan komersil ayam sentul umur 12 minggu. Hal ini di sebabkan karena pada umur tersebut perkembangan otot pada ayam belum berkembang secara maksimal, sehingga pengaruh gen MSTN yang bekerja sebagai regulator negatif otot belum terlihat. Menurut Hidayat dan Sopiyana 
(2010) ayam sentul dapat mencapai bobot badan maksimal 1960 gram.

Hasil analisis statistik menunjukkan perbedaan yang signifikan $(\mathrm{P}<0,05)$ pada bobot hidup, bobot potong dan bobot karkas pada ayam sentul umur 20 minggu. Hal ini menunjukkan bahwa keragaman gen MSTN pada ekson 2 memiliki asosiasi terhadap bobot potong, bobot karkas, bobot potongan komersial ayam sentul umur 20 minggu. Menurut Bhattacharya dan Chatterjee (2013) Gen MSTN berpengaruh signifikan terhadap sifat pertumbuhan pada ayam. Gen MSTN berasosiasi dengan bobot karkas dan potongan karkas ayam (Khaerunnisa et al. 2016).

Kelompok kontrol menunjukkan genotipe GG memiliki bobot hidup, bobot potong, bobot karkas, dan bobot potongan karkas yang lebih tinggi dibandingkan dengan genotipe GT dan TT. Persentase karkas pada setiap genotipe tidak menunjukkan pengaruh yang signifikan $(\mathrm{P}<0,05)$. Hal ini tidak sesuai dengan penelitian yang dilakukan oleh Khaerunnisa et al. (2016) bahwa genotipe TT dan GT memiliki bobot karkas yang lebih tinggi dibandingkan dengan genotipe GG.

\section{KESIMPULAN}

Gen MSTN pada populasi ayam sentul bersifat polimorfik. Pengaruh genotipe tidak berinteraksi dengan kelompok perlakuan (Kontrol, KLH, dan KLH-MSTN). Gen MSTN berasosiasi dengan bobot daging thighs, persentase bobot thighs, persentase bobot daging thighs pada umur 12 minggu. Gen MSTN berasosiasi dengan bobot hidup, bobot potong, bobot karkas dan bobot potongan karkas pada umur 20 minggu.

\section{DAFTAR PUSTAKA}

Allendorf FW, Luikart G, Aitken SN. 2013. Conservation and The Genetics of Populations. Ed ke-2. Oxford (UK): Blackwell Publishing.

Armand AS, Della Gaspera B, Launay T, Charbonnier F, Gallien CL, Chanoine C. 2003. Expression and neural control of follistatin versus myostatin genes during regeneration of mouse soleus. $J A A A$. 227: 256-65.

Bhattacharya TK, R Shukla, RN Chatterjee, K Dushyanth. 2017. Knock down of the myostatin gene by RNA interference increasedbody weight in chicken. $J$ Biotechnol. 241: 61-68.

Hartl DL, Clark AG. 1997. Principle of Population Genetic. Sunderland (UK): Sinauer Associates, (MA).

Hidayat C, Sopiyana S. 2010. Potensi Ayam Sentul sebagai Plasma Nutfah Asli Ciamis Jawa Barat. Balai Penelitian Ternak, PO Box 221, Bogor 16002

Khaerunnisa I, M Pramujo, II Arief, C Budiman, A Gunawan, Jakaria, C Sumantri. 2016. Polymorphism of the T4842G Myostatin Gene is Associated with Carcass Characteristics in Indonesian Chickens. Intl. J. Poult. Sci. 15 (8): 316-324.

Kirk S, Oldham J, Kambadur R, Sharma M, Dobbie P, Bass J. 2000. Myostatin regulation during skeletal muscle regeneration. J Cell Physiol 184: 356-63.

Kubota K, F Sato, S Aramaki, T Soh, N Yamauchi, M Hattori. 2007. Ubiquitous expression of myostatin in chicken embryonic tissues: its high expression in testis and ovary. Comp. Biochem Phys. A. 148:550-555.

Lalani R, Bhasin S, Byhower F, Tarnuzzer R, Grant M, et al. 2000. Myostatin and insulin-like growth factor-I and -II expression in the muscle of rats exposed to the microgravity environment of the NeuroLab space shuttle flight. J Endocrinol. 167: 417-28.

Mattjik AA \& Sumertajaya IM. 2002. Perancangan Percobaan dengan Aplikasi SAS dan Minitab. Bogor : Institut Pertanian Bogor

Mendler L, Zador E, Ver Heyen M, Dux L, Wuytack F. 2000. Myostatin levels in regenerating rat muscles and in myogenic cell cultures. J Muscle Res Cell Motil 21: 551-63.

Moon YS, Lee HG, Yin YH, Jin X, Hong ZS, Cho JS, Choi YJ. 2005. Effect of maternal passive autoimmunization against myostatin on growth performance in chickens. Asian-Aust J Anim Sci. 7 : 1017-1021.

Najl TAA, Amadou I, Zhao RY, Tang X, Shi YH, Le GW. 2014. Effects of phytosterol in feed on growth and related rene expression in muscles of broiler chicken. Trop J Pharm Res. 13 (1): 9-16.

Nei, Kumar. 2000. Molecular Evolution and Phylogenetics. New York (US): Oxford University Press.

Priyatno, M. A. 2000. Mendirikan Usaha Pemotongan Ayam. Cetakan Ketiga. Jakarta (ID): Penebar Swadaya.

Sambrook J, Fritsch Ef, Maniatis T. 1989. Moleculer Cloning: A Laboratory Manual. New York (USA): Cold Spring Harbour Lab Pr.

Wehling M, Cai B, Tidball JG. 2000. Modulation of myostatin expression during modified muscle use. FASEB J.14: 103-10.

Whittemore LA, Song K, Li X, Aghajanian J, Davies $\mathrm{M}$, et al. 2003. Inhibition of myostatin in adult mice increases skeletal muscle mass and strength. Biochem biophys res commun. 300: 965-71.

Ye X, Brown SR, Nones K, Coutinho LL, Dekkers JC, Lamont SJ. 2007. Association of myostatin gene polymer-phisms with performance and mortality traits in broiler chickens. Gene Sel Evol. 39:73-89.

Zhang G, Zhao XH, Wang JY, Ding FX, Zhang L. 2011. Effect of an exon 1 mutation in the myostatin gene on the growth traits of the Bian chicken. Anim Genet: 43: 458-459. 